\title{
Identification of Potentially Hazardous Microorganisms and Assessment of Physicochemical Deterioration of Thermally Processed King Coconut (Cocos nucifera var. aurantiaca) Water under Different Processing Conditions in Sri Lanka
}

\author{
Maheshika Dilrukshi Jayasinghe $\mathbb{D}^{\mathbb{D}},{ }^{1}$ Samantha Sanath Kumara Madage $\mathbb{D}$, \\ Ilmi Ganga Namali Hewajulige $\mathbb{D}^{\mathrm{D}}$, \\ Thalawaththe Muhandiramlage Dilini Ayesha Jayawardana $\mathbb{D},{ }^{1}$ \\ Anupama Prabashini Halmillawewa $\mathbb{D}^{2}{ }^{2}$ \\ and Divisekera Mudiyanselage Wasundara Devanmini Divisekera $\mathbb{D}^{1}$ \\ ${ }^{1}$ Food Technology Section, Modern Research and Development Complex, Industrial Technology Institute, Malabe, Sri Lanka \\ ${ }^{2}$ Department of Microbiology, Faculty of Science, University of Kelaniya, Kelaniya, Sri Lanka \\ Correspondence should be addressed to Divisekera Mudiyanselage Wasundara Devanmini Divisekera; wasu@iti.lk
}

Received 17 September 2021; Accepted 20 December 2021; Published 27 February 2022

Academic Editor: Chunpeng Wan

Copyright (C) 2022 Maheshika Dilrukshi Jayasinghe et al. This is an open access article distributed under the Creative Commons Attribution License, which permits unrestricted use, distribution, and reproduction in any medium, provided the original work is properly cited.

\begin{abstract}
King coconut water (KCW) is a sweet relish product that is more prone to rapid quality deterioration, and several safety concerns are emerging due to its inappropriate thermal processing. Therefore, the objective of this study was to identify the potential spoilage/ pathogenic microorganisms associated with the processing of KCW, with the assessment of possible physicochemical changes as providing preliminary information required for the thermal process validation of bottled KCW. Samples $(n=6,150 \mathrm{ml} / \mathrm{sample})$ were collected from three different KCW processing facilities at five critical processing steps $\left(P_{1}-P_{5}\right)$. A facility survey, physicochemical analyses, and microbial enumeration and isolation, along with their molecular identifications, were conducted. It was found that all tested physicochemical properties were significantly changed $(p<0.05)$ among sampling points at each processing facility. The colour of thermally processed KCW samples has significantly changed $(p<0.05)$ compared to the fresh KCW, which causes a distinct effect on the appealing quality of the final product. A pattern of initial lower counts with gradually increased microbial counts at intermediate processing steps $\left(1.0 \times 10^{3}-5.3 \times 10^{6} \mathrm{CFU} / \mathrm{ml}\right)$ and significantly lowered $(p<0.05)$ counts after thermal treatment was observed. Among the bacterial and fungal isolates identified, several potential pathogenic bacterial species, such as Pantoea dispersa, Bacillus siamensis, Pseudomonas stutzeri, and Acinetobacter lactucae; a few thermal resistant yeasts, Pichia kudriavzevii, Debaryomyces nepalensis, and Candida carpophila; and moulds, Penicillium citrinum, Microdochium fisheri, and Trichosporon asahii, have survived in the thermally processed KCW. Based on the results of the study, it is suggested that the thermal process validation of KCW should be targeted according to the revealed knowledge on the identified hazardous microorganisms, while adhering to Good Manufacturing and Hygienic Practices with minimized handling time to avoid rapid quality deterioration.
\end{abstract}

\section{Introduction}

King coconut (Cocos nucifera var. aurantiaca) is endemic to Sri Lanka, which possesses splendid nutritional and therapeutic values. It is one of the fastest growing export commodities in the food and beverage sector in Sri Lanka, which has contributed Rs. 600 million of foreign exchange in the year 2020 [1]. Sri Lankan king coconut water is highly demanded in the international market due to its unique quality and sensory characteristics compared to regular green coconuts. It is rich in invert sugars (glucose and fructose), electrolytes $\left(\mathrm{Na}^{+}, \mathrm{K}^{+}, \mathrm{Ca}^{+2}\right.$, and $\left.\mathrm{Mg}^{+2}\right)$, and amino 
acids (arginine, alanine, and cysteine), along with hepatoprotective, antidiabetic, antipyretic, and antihypertensive effects [2].

King coconut water is a relatively clear, colourless liquid, which is sterile as long as it remains in the nut [3]. However, it is more prone to lose its wholesomeness once it is extracted from the nut, causing rapid deterioration due to microbial contamination and physicochemical changes over time. Several quality issues, such as pink discolouration, off-flavour, and odour development, have been experienced in the king coconut water industry with emerging safety concerns due to inadequate thermal processing. In recent times, as there is a prime concern in "Safe Human Consumption" for thermally processed foods, several safety regulations have been implemented by the Food and Drug Administration (FDA) to ensure the quality and safety of thermally processed foods [4].

As per the Code of Federal Regulations (CFR) implemented by the FDA $[4,5]$, it is essential to establish the "Schedule Process" by the process authority to ensure thermal inactivation $(12 \mathrm{D}$ or $7 \mathrm{D})$ of potentially pathogenic microorganisms in canned/bottled foods. Currently, Clostridium botulinum and Clostridium pasteurianum are generally being targeted for thermal process validations for lowacid canned foods (LACF) and acidified foods (AF), respectively [6].

However, it is important to practice a well-focused thermal treatment rather than using a total killer method just to comply with quality and safety regulations $[4,5]$. Moreover, thermal treatment with nontargeted time-temperature combinations leads to cause overcooking/undercooking in certain heat-sensitive food products, such as king coconut water, coconut water, and fruit juices [6]. Therefore, specific knowledge on the microbial quality of a particular food matrix is vitally important to minimize the possible quality defects. As very limited research evidence is available on the precise identification of microorganisms associated with the king coconut water bottling process, this present study was conducted as an effective approach to provide the baseline information required for the thermal process validation of king coconut water as a timely requirement.

\section{Materials and Methods}

2.1. Processing Facility Survey and Sample Collection. Three king coconut water processing facilities, identified as Facility I (JA), Facility II (SM), and Facility III (CW), were surveyed for currently practiced Good Manufacturing Practices (GMP) and Good Hygienic Practices (GHP) based on visual observations using a prestructured checklist ( $\mathrm{Ta}-$ ble 1) prepared according to the guidelines given by the Food and Agriculture Organization (FAO) for coconut water processing industries [7]. King coconut water samples were collected from three selected processing facilities at five critical processing steps: king coconut water extraction $\left(P_{1}\right)$, bulk nut water collection $\left(P_{2}\right)$, standardization $\left(P_{3}\right)$, pre-heat treatment before hot filling $\left(P_{4}\right)$, and thermally processed end product $\left(P_{5}\right)$. Altogether, six samples $(n=6)$ were collected at each sampling point in each premise.
Samples were hygienically collected into aseptic stomacher bags (Seward ${ }^{\circledR}, \mathrm{UK}$ ) and were transported to the microbiology laboratory, Industrial Technology Institute, within $6 \mathrm{hr}$, under chilled conditions $\left(4 \pm 1^{\circ} \mathrm{C}\right)$ and stored in a refrigerator until the onset of analysis.

2.2. Physicochemical Analyses. King coconut water samples collected from three processing facilities at $P_{1}-P_{5}$ were tested for colour, $\mathrm{pH}$, total soluble solids (TSS), and total sugar content. The CIE (International Commission of Illumination) lab space method [8] was used to measure the colour using a digital chroma meter (Konica Minolta CR410 , Japan). The degree of colour difference $(\Delta E)$ compared to fresh king coconut water was calculated using a formula as follows [8]:

$$
\Delta E=\sqrt{\Delta L^{* 2}+\Delta a^{* 2}+\Delta b^{* 2}},
$$

where, $\Delta L^{*}, \Delta a^{*}$, and $\Delta b^{*}$ refer to the degree of difference in lightness $\left(L^{*}\right)$, hue between red and green $\left(a^{*}\right)$, and hue between blue and yellow $\left(b^{*}\right)$ compared to fresh king coconut water, respectively.

The $\mathrm{pH}$ was measured using a digital $\mathrm{pH}$ meter (Eutech $\mathrm{pH} 510$ Model, USA) at $25^{\circ} \mathrm{C}$ and TSS was measured using a handheld refractometer (Atago, S-28, Japan) at $25^{\circ} \mathrm{C}$ [9]. Total sugar content was measured according to a modified method of ISO 10504 [10] using the HPLC-RQ chromatographic system (Agilent, 1260 Infinity, USA). The chromatographic separation was achieved on an analytical column $(7.8 \mathrm{~mm} \times 300 \mathrm{~mm}, 5 \mu \mathrm{m})$ (Phenomenex, Rezex ROA Organic Acid $\mathrm{H}^{+} 8 \%$, USA) and a guard column $(4.6 \mathrm{~mm} \times 12.5 \mathrm{~mm}, 5 \mu \mathrm{m})$ (Phenomenex, Rezex, USA). Peaks were identified as retention time (RT), as shown by the respective peaks of standard sugar solutions and quantified as area under the curve using programmed software (OpenLab CDS, ChemStation Edition C.01.09) coupled with HPLC.

2.3. Enumeration of Microorganisms. King coconut water samples collected at each sampling point $\left(P_{1}-P_{5}\right)$ from three processing facilities were serially diluted using $0.89 \%$ $\mathrm{NaCl}(\mathrm{w} / \mathrm{v})$, cultured on Plate Count Agar (PCA) (Oxoid, UK) and Dichloran Rose-Bengal Chloramphenicol Agar (DRBC) (Oxoid, UK), and aerobically incubated at $30 \pm 1^{\circ} \mathrm{C}$ for $72 \pm 3 \mathrm{hr}$ and $25 \pm 1^{\circ} \mathrm{C}$ for $2-5$ days, respectively. Pour plate technique was used for PCA and spread plate technique was used for DRBC as depicted in the respective international standards: ISO 4833-1:2013 [11] and ISO 21527-1: 2008 [12]. The detection and enumeration of coliforms and Escherichia coli were carried out using the Most Probable Number (MPN) technique according to the ISO 4831:2006 [13] and ISO 7251:2005 [14] standards, respectively.

2.4. Isolation and Identification of Microorganisms. King coconut water samples were serially diluted up to selective concentrations with sterilized saline $(0.89 \% \mathrm{NaCl} \mathrm{w} / \mathrm{v})$, plated on four culture media, Nutrient Agar (NA) (Oxoid), 
TABLE 1: Processing conditions observed at each processing facility during the facility survey.

\begin{tabular}{|c|c|c|c|c|}
\hline \multicolumn{2}{|r|}{ FAO criteria on GMP/GHP [7] } & JA & SM & $\mathrm{CW}$ \\
\hline \multirow{2}{*}{ Nut receiving } & 1. Systematic unloading of king coconut water & $\sqrt{ }$ & $\times$ & $\sqrt{ }$ \\
\hline & 2. Examination for damaged or immature nuts & $\sqrt{ }$ & $\times$ & $x$ \\
\hline \multirow{6}{*}{ Nut water extraction } & 3. Nut washing with sanitizers & $\sqrt{ }$ & $\times$ & $x$ \\
\hline & 4. Frequent change of wash-water & $\sqrt{ }$ & $x$ & $x$ \\
\hline & 5. Sanitization of tools and implements for processing & $\sqrt{ }$ & $\sqrt{ }$ & $\sqrt{ }$ \\
\hline & 6. Processing environment with free of animals, trees, insects, dust, and garbage & $\sqrt{ }$ & $x$ & $\sqrt{ }$ \\
\hline & 7. Physically separated king coconut water extraction area and bottling area & $\sqrt{ }$ & $\sqrt{ }$ & $\sqrt{ }$ \\
\hline & 8. Immediate disposal of waste material (king coconut husk) from processing environment & $\sqrt{ }$ & $\sqrt{ }$ & $\sqrt{ }$ \\
\hline \multirow{5}{*}{ Nut water processing } & 9. Cooling after extraction/chilling tanks (when collecting of larger volumes) & $\times$ & $\sqrt{ }$ & N/A \\
\hline & 10. Transferring to temporary storage tanks & $\sqrt{ }$ & $\sqrt{ }$ & $\times$ \\
\hline & 11. Sanitization of bottles and caps & $\times$ & $\sqrt{ }$ & $x$ \\
\hline & 12. Handwashing & $\sqrt{ }$ & $\sqrt{ }$ & $\sqrt{ }$ \\
\hline & 13. Eat/talk/smoke prohibited while working & $\sqrt{ }$ & $\sqrt{ }$ & $\sqrt{ }$ \\
\hline \multirow{4}{*}{$\begin{array}{l}\text { Personal } \\
\text { hygiene }\end{array}$} & 14. Wear clean clothes/aprons & $\sqrt{ }$ & $\sqrt{ }$ & $\sqrt{ }$ \\
\hline & 15. Physically fit for work & $\sqrt{ }$ & $\sqrt{ }$ & $\sqrt{ }$ \\
\hline & 16. Clean hands/wear gloves & $\sqrt{ }$ & $\sqrt{ }$ & $\sqrt{ }$ \\
\hline & 17. Cover hair/beard & $\sqrt{ }$ & $\sqrt{ }$ & $\sqrt{ }$ \\
\hline
\end{tabular}

Three studied king coconut water processing facilities are denoted as Facility I (JA), Facility II (SM), and Facility III (CW); FAO refers to "Food and Agriculture Organization", GMP refers to "Good Manufacturing Practices"; GHP refers to "Good Hygienic Practices"; Presence of each condition is indicated as " $\sqrt{ }$ " and the absence of each condition is indicated as " $x$ "; N/A refers to "Not Applicable."

Potato Dextrose Agar (PDA) (Oxoid), Eosin Methylene Blue Agar (EMB) (Oxoid), and Reasoner's 2A Agar (R2A) (Oxoid), and were incubated aerobically at $30 \pm 1{ }^{\circ} \mathrm{C}$ for $48 \mathrm{hr}, 25 \pm 1^{\circ} \mathrm{C}$ for $2-5$ days, and $37 \pm 1^{\circ} \mathrm{C}$ for $48 \mathrm{hr}$, respectively. Isolated single colonies were purified by repeated streak plating and morphologically characterized using colony characteristics: colour, size, shape, margin, elevation, and consistency [15]. Bacterial colonies were initially screened by Gram's staining [16] and fungal colonies were stained by lactophenol cotton blue [17] observed under a compound light microscope (Olympus, UK).

Genomic DNA extractions of bacterial and fungal isolates were done as per the methods given in Moore et al. [18] and Aamir et al. [19], respectively. The 16S rRNA gene amplification of bacterial isolates was carried out by PCR thermocycler (Peltier Thermal Cycler PTC-225, Macrogen, South Korea) using universal primers: 27F (5'GAGTTTGAT CATGGCTCAG3 ${ }^{\prime}$ ) and 1492R (5'GGTTACCTTGTTAC GACTT3 $^{\prime}$ ) [20] and sequenced by 785F (5'GGATTAGATA CCCTGGTA $\left.3^{\prime}\right)$ and 907R (5'CCGTCAATTCMTTTRAG TTT3 $^{\prime}$ ) primers [21]. Eukaryotic nuclear rRNA/ITS genes of fungal isolates were amplified and sequenced using ITS1 (5'TCCTCCGCTTATTGATATGC $3^{\prime}$ ) and ITS4 (5'GGA AGTAAAAGTCGTAACAAGG3 ${ }^{\prime}$ ) as forward and reverse primers, respectively [22].

Sequences of each isolate were aligned to obtain contiguous sequences using Bioedit Sequence Alignment Editor 7.2 (Ibis Therapeutics, Carlsbad, CA). The database search for homologous sequences was performed by the Basic Local Alignment Tool (BLAST) of the National Center for Biotechnology Information (NCBI). Sequences with an identity of $98-99 \%$ or higher compared to those in databases and with e-values of $<10 e-100$ were allocated to the same species. The partial gene sequences of 16S rRNA bacterial isolates and eukaryotic nuclear rRNA/ITS fungal isolates were deposited at GenBank, NCBI, USA (Accession nos.: MT798808-
MT804631, MT826212-MT826241, and MT875242MT880733).

The contig sequences of bacterial and fungal species isolated from the three studied factory premises were aligned with ClustalW 2.1 software, separately. Phylogenetic analyses were conducted using MEGA 7 [23, 24]. The evolutionary history was inferred using the neighbor-joining method $[25,26]$.

2.5. Statistical Analysis. All experiments were conducted in a completely randomized design for each premise with replicates $(n=6)$. Data were analyzed at a $95 \%$ confidence interval using one-way ANOVA and the mean comparison was done by Tukey's family error rate test. The mean and standard deviations were calculated using MINITAB 14.

\section{Results and Discussion}

3.1. Processing Facility Survey. Similar unit operations with varying degrees of operational/processing conditions were observed at pre-identified critical sampling points $\left(P_{1}-P_{5}\right)$ in each studied processing facility. The status of the currently practiced GMP and GHP was monitored as preliminary information, which directly influences the quality and safety of the final product (Table 1).

A detailed comparison with critical processing conditions, including mode of operation, degree of mechanization, and labour involvement at individual processing facilities, is given in Table 2. The major observations on processing methods/processing environment, which is led by the physicochemical changes and the microbial/hygienic quality at each processing facility, are discussed in the sections, as given below. 
TABle 2: Detailed description of observations made at each sampling point in the studied king coconut water processing facilities.

\begin{tabular}{|c|c|c|c|}
\hline Process parameters & Facility I (JA) & Facility II (SM) & Facility III (CW) \\
\hline \multicolumn{4}{|l|}{$\begin{array}{l}\text { Process/operating } \\
\text { conditions }\end{array}$} \\
\hline Mode of operation & Semiautomated process & Automated process & Manual process \\
\hline Batch size & $300-500 \mathrm{~L} / \mathrm{batch}$ & $2000-2500 \mathrm{~L} / \mathrm{batch}$ & $50-100 \mathrm{~L} / \mathrm{batch}$ \\
\hline $\begin{array}{l}\text { Degree of manual } \\
\text { handling }\end{array}$ & Moderate manual handling & Limited manual handling & Excessive manual handling \\
\hline \multicolumn{4}{|l|}{$\begin{array}{l}\text { Conditions at sampling } \\
\text { points }\end{array}$} \\
\hline \multirow{2}{*}{$\begin{array}{l}\text { Nut water extraction } \\
\qquad\left(P_{1}\right)\end{array}$} & $\begin{array}{l}\text { Practice in a close } \\
\text { environment }\end{array}$ & Practice at an open environment & Practice in a close environment \\
\hline & $\begin{array}{l}\text { Nut splitting using knives } \\
\text { Nut washing is practiced }\end{array}$ & $\begin{array}{l}\text { Pierce the nut on a sharp edge } \\
\text { No nut washing }\end{array}$ & $\begin{array}{l}\text { Nut splitting using knives } \\
\text { No nut washing }\end{array}$ \\
\hline \multirow{3}{*}{$\begin{array}{l}\text { Bulk nut water } \\
\text { collection } \quad\left(P_{2}\right)\end{array}$} & Prolonged collection time & Moderately rapid collection time & Rapid collection \\
\hline & Bulk tanks are used & Chilled tanks are used & Use temporary containers \\
\hline & Unsystematic way of filtration & Practice nut water filtration & Practice nut water filtration \\
\hline $\begin{array}{l}\text { Acidification/ } \\
\text { standardization } \\
\qquad\left(P_{3}\right)\end{array}$ & $\begin{array}{c}\text { Practice acidification step } \\
\text { (ascorbic acid) }\end{array}$ & $\begin{array}{l}\text { No acidification step (add pineapple } \\
\text { juice to mask colour) }\end{array}$ & $\begin{array}{l}\text { Practice acidification step (citric and } \\
\text { ascorbic acid) }\end{array}$ \\
\hline Preheat treatment & $60-70^{\circ} \mathrm{C}$ practice hot filling & $60-65^{\circ} \mathrm{C}$ practice aseptic filling & $60-70^{\circ} \mathrm{C}$ practice hot filling \\
\hline prior to hot filling $\left(P_{4}\right)$ & Practice bottle washing & $\begin{array}{c}\text { No bottle washing step (aseptic cartons } \\
\text { are used) }\end{array}$ & No bottle washing \\
\hline \multirow{2}{*}{$\begin{array}{l}\text { Final thermal treatment } \\
\qquad\left(P_{5}\right)\end{array}$} & $\begin{array}{l}\text { Pasteurization }\left(100^{\circ} \mathrm{C} \text { for }\right. \\
12.5 \mathrm{~min})\end{array}$ & Sterilization $\left(140^{\circ} \mathrm{C}\right.$ for $\left.3 \mathrm{~s}\right)$ & Pasteurization $\left(100^{\circ} \mathrm{C}\right.$ for $\left.20 \mathrm{~min}\right)$ \\
\hline & Water bath (automatic) & UHT processing plant (automatic) & Water bath (manual) \\
\hline Nature of the final product & Bottle & UHT pack & Bottle \\
\hline \multicolumn{4}{|l|}{ Overall GMP/GHP } \\
\hline Overall GMP status & Complying with GMP & Complying with GMP & Not complying with GMP \\
\hline Overall GHP status & Complying with GHP & Complying with GHP & Not complying with GHP \\
\hline
\end{tabular}

3.2. Physicochemical Analyses. According to statistical analyses, all tested physicochemical parameters (colour, $\mathrm{pH}$, TSS, and total sugars) were significantly differed $(p<0.05)$ among sampling points at Facility I (JA) and Facility II (SM). In contrast, Facility III (CW) has shown a significant difference $(p<0.05)$ in $\mathrm{pH}$ and colour, while TSS and total sugar content among $P_{1}-P_{5}$ were not significantly changed.

The changes in colour $(\Delta \mathrm{E}), \mathrm{pH}$, TSS, and total sugar content among $P_{1}-P_{5}$ in the studied processing facilities are given in Figure 1 and Table 3, respectively. The lowest colour difference compared to fresh king coconut water was shown at Facility I (JA), where they practiced pasteurization $\left(100^{\circ} \mathrm{C}\right.$ for $12.5 \mathrm{~min}$ ) under controlled temperature conditions (Figure 1). In contrast, a comparatively higher colour difference was observed in Facility III compared to Facility I due to a prolonged pasteurization process $\left(100^{\circ} \mathrm{C}\right.$ for $\left.20 \mathrm{~min}\right)$ under manually operated heating conditions. However, a significantly higher $(p<0.05)$ colour difference has been observed in $\mathrm{Fa}-$ cility II (SM), where ultraheat treatment (UHT) was practiced with added fruit blends (pineapple juice). Since Facility I (JA) and Facility III (CW) perform low-temperature treatments (pasteurization), colour preservation is comparatively higher than Facility II (SM), where high-temperature treatments (sterilization) are implemented.

According to the literature, most industries use fruit blends to mask the off-colour of thermally processed coconut water [27]. However, it is important to preserve the natural colour while avoiding excessive heat treatment. The changes in physicochemical parameters of king coconut water mainly affect the quality of the final product. Discolouration, off-flavour, and turbidity (cloudiness) development have been identified as the main quality defects of thermally processed king coconut water [28, 29].

However, the colour of thermally processed king coconut water is highly influenced by the degree of thermal treatment as it may lead to initiate browning reactions $[3,30]$. Nonenzymatic browning has also been found to result from several reactions, including Maillard reaction, caramelization and acid hydrolyzation (ascorbic acid), and degradation of pigments [31, 32]. Similarly, Lima et al. [33] and Carvalho et al. [34] reported the darkening of beverages composed of coconut water due to oxidation reactions during storage. Furthermore, Chaunhan et al. [35] reported that the CIE $L^{*}$ (lightness) values of coconut beverages were significantly decreased $(p<0.05)$ during processing. Therefore, the colour of thermally processed king coconut water should be taken into consideration to maintain the appealing quality of the product.

Apart from the colour, $\mathrm{pH}$, TSS, and total sugar content are also considered as critical factors affecting the quality and sensory attributes of king coconut water. The $\mathrm{pH}$ is one of the most critical parameters to be controlled in thermally processed food products. As per the FDA 


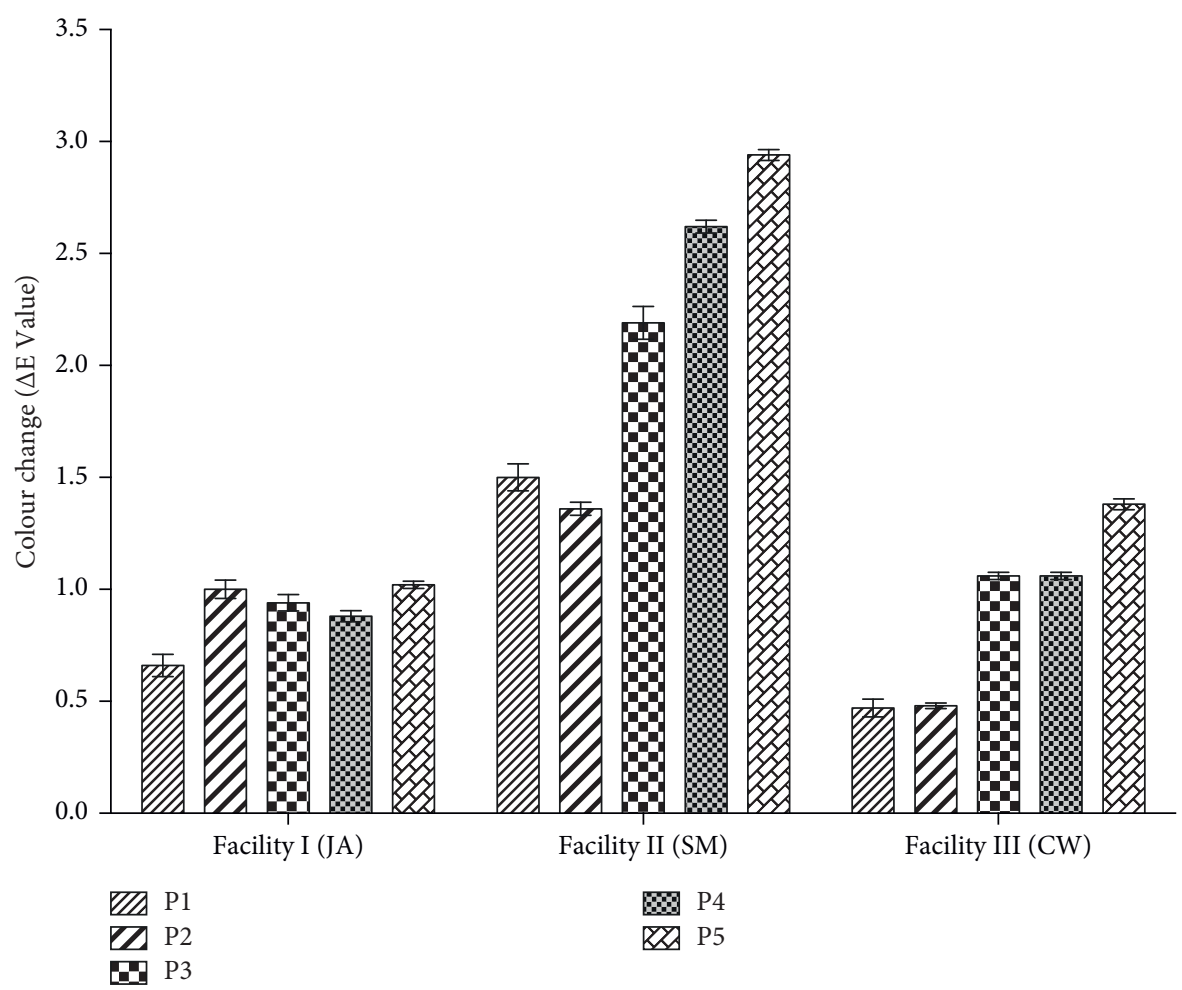

FIGURE 1: The colour changes of king coconut water among sampling points at each processing facility. Pre-identified five different sampling points are denoted as $P_{1}, P_{2}, P_{3}, P_{4}$, and $P_{5}$, respectively; three studied processing facilities are denoted as JA, SM, and CW. Error bars indicate SD.

TABLE 3: Changes in physicochemical parameters of king coconut water along the process line.

\begin{tabular}{|c|c|c|c|c|}
\hline Factory ID & Sampling points & $\mathrm{pH}\left(\right.$ at $\left.25^{\circ} \mathrm{C}\right)$ & TSS (Brix) & Total sugars (\%) \\
\hline Facility I (JA) & $\begin{array}{l}P_{1} \\
P_{2} \\
P_{3} \\
P_{4} \\
P_{5}\end{array}$ & $\begin{array}{l}4.68 \pm 0.01^{a} \\
4.61 \pm 0.01^{b} \\
4.50 \pm 0.01^{c} \\
4.51 \pm 0.02^{c} \\
4.57 \pm 0.02^{d}\end{array}$ & $\begin{array}{l}5.1 \pm 0.1^{a} \\
5.1 \pm 0.0^{a} \\
5.0 \pm 0.0^{a} \\
4.7 \pm 0.1^{b} \\
5.0 \pm 0.2^{a}\end{array}$ & $\begin{array}{l}5.6 \pm 0.1^{a} \\
3.9 \pm 0.2^{e} \\
4.6 \pm 0.1^{c} \\
5.1 \pm 0.1^{b} \\
4.3 \pm 0.0^{d}\end{array}$ \\
\hline Facility II (SM) & $\begin{array}{l}P_{1} \\
P_{2} \\
P_{3} \\
P_{4} \\
P_{5}\end{array}$ & $\begin{array}{c}4.81 \pm 0.01^{c} \\
4.77 \pm 0.02^{d} \\
4.84 \pm 0.01^{b c} \\
4.86 \pm 0.02^{b} \\
4.98 \pm 0.02^{a}\end{array}$ & $\begin{array}{l}5.1 \pm 0.1^{c} \\
5.0 \pm 0.0^{c} \\
5.3 \pm 0.2^{b} \\
5.2 \pm 0.1^{b c} \\
5.6 \pm 0.1^{a}\end{array}$ & $\begin{array}{l}5.5 \pm 0.1^{a} \\
5.2 \pm 0.1^{b} \\
5.5 \pm 0.1^{a} \\
5.4 \pm 0.0^{a} \\
5.2 \pm 0.0^{b}\end{array}$ \\
\hline Facility III (CW) & $\begin{array}{l}P_{1} \\
P_{2} \\
P_{3} \\
P_{4} \\
P_{5}\end{array}$ & $\begin{array}{l}4.56 \pm 0.06^{a} \\
4.45 \pm 0.05^{b} \\
4.50 \pm 0.01^{b} \\
4.47 \pm 0.02^{c} \\
4.53 \pm 0.01^{d}\end{array}$ & $\begin{array}{l}4.9 \pm 0.1^{c} \\
4.9 \pm 0.1^{c} \\
5.0 \pm 0.1^{c} \\
5.0 \pm 0.1^{c} \\
5.0 \pm 0.1^{c}\end{array}$ & $\begin{array}{l}5.3 \pm 0.1^{c} \\
5.3 \pm 0.1^{c} \\
5.3 \pm 0.1^{c} \\
5.2 \pm 0.1^{c} \\
5.2 \pm 0.1^{c}\end{array}$ \\
\hline
\end{tabular}

Data are expressed as mean \pm SD, $n=6$. Significant difference $(p<0.05)$ is denoted as lowercase letters within a column for each king coconut processing facility. Three studied processing facilities are denoted as Facility I (JA), Facility II (SM), and Facility III (CW). Pre-identified five different sampling points are denoted as $P_{1}$, nut water extraction; $P_{2}$, bulk collection; $P_{3}$, acidification; $P_{4}$, pre-heat treatment; $P_{5}$, sterilization/pasteurization, respectively.

guidelines of 21 CFR Parts 113 and $114[4,5]$, all products with a $\mathrm{pH}>4.6$ shall be processed at high-temperature short time (HTST) sterilization conditions, while products with a $\mathrm{pH} \leq 4.6$ shall be processed at low-temperature long time (LTLT) pasteurization conditions. Therefore, maintaining the optimum $\mathrm{pH}$, which suits the processing method as given in the FDA guidelines, has been a real challenge in industrial aspects.
As shown in Table 3, the $\mathrm{pH}$ of king coconut water has been lowered below 4.6 at $P_{3}$ in both Facility I (JA) and Facility III $(\mathrm{CW})$ via acidification process in order to practice pasteurization. Facility II (SM) did not perform any acidification (Table 2) since they have employed the HTST sterilization technique. Ascorbic acid (AA) and a combination of ascorbic and citric acid were used as acidulants in Facility I (JA) and Facility III (CW), respectively. Ascorbic 
acid is a well-known heat-labile acidifying agent [35] and citric acid is capable of withstanding the heat. A clear $\mathrm{pH}$ increase after the thermal treatment (Table 3), even after being adjusted below 4.6 in this study, could be explained by several ways, such as heat stability of the added acidulants, facilitated dissolution of soluble solids, and oxidation of ascorbic acid, as similarly presented by Marti et al. [36] and Kabasakalis et al. [37].

TSS and total sugar content of king coconut water processed at Facility II (SM) have significantly fluctuated $(p<0.05)$ among sampling points as pineapple juice was added to the product at $P_{3}$. TSS content is a measure of soluble solids, which is mainly contributed as sugars present in a particular product. There was a significant decrease $(p<0.05)$ in the TSS and sugar content at $P_{1}-P_{3}$ in Facility I (JA), which may be attributed to the sugar fermentation along with prolonged collection time with larger batch sizes. In contrast, TSS and sugar content were not significantly changed $(p<0.05)$ in Facility III $(\mathrm{CW})$ due to rapid processing with smaller batch size. Significant reduction in sugar content of king coconut water after thermal treatment may be attributed to the acid hydrolysis of the nonreducing sugars (sucrose) at low $\mathrm{pH}$ values $[33,34]$.

3.3. Enumeration of Microorganisms. Results of this study revealed that the bacterial, yeast, and mould (Y\&M) counts were significantly differed $(p<0.05)$ among sampling points in each of the three studied processing facilities (Figures 2 and 3). No bacterial counts were detected in thermally processed king coconut water $\left(P_{5}\right)$, at all studied processing facilities (Figure 2), when cultured in PCA. In contrast, only Facility III (CW) had Y\&M counts in king coconut water samples even after the thermal treatment $\left(P_{5}\right)$, while no colonies were detected in the thermally processed products at Facility I (JA) and Facility II (SM).

Results emphasized that the currently practiced heat treatments may be effective in terms of inhibition of bacterial and fungal growth in king coconut water processed at $\mathrm{Fa}$ cility I (JA) and Facility II (SM) compared to that processed at Facility III (CW). Since CW practices pasteurization at $100^{\circ} \mathrm{C}$ for $20 \mathrm{~min}$ in a manually operated water bath along with an inefficient cooling method, the comparatively higher fungal counts at $P_{5}$ suggests that the heat treatment may not be effective in preventing fungal growth (thermal resistant spores) in CW with the currently practiced hygienic and manufacturing methods. Therefore, it is vitally important to trace back the possible sources of contamination via frequent monitoring and supervision on process hygiene and handling processes in order to minimize cross-contamination.

However, the association of bacterial and Y\&M counts among sampling points has shown a bell-shaped pattern, where it started from considerable initial counts, while reaching its maximum at intermediate steps $\left(P_{1}-P_{3}\right)$ and drastically receding at $P_{5}$ after thermal treatment. A similar pattern of microbial counts at processing lines of sweet potato puree and citrus-processing facilities was reported by Malavi et al. [38] and Parish [39], respectively. Therefore, the implementation of appropriate cleaning and sanitation protocols should be highly considered.

The existing hygienic and microbial quality at the primary processing steps $\left(P_{1}-P_{3}\right)$ at each processing facility was well supported by the observations made at the facility survey. Significantly lower $(p<0.05)$ initial microbial load detected at the nut water extraction in Facility I (JA) was well supported by the nut washing step with chlorinated water, observed at the facility survey (Table 2 ). However, a significantly higher $(p<0.05)$ microbial load (bacterial and Y\&M counts) has been detected at the bulk nut water collection $\left(P_{2}\right)$ in Facility I (JA) (Figures 2 and 3), where prolonged time was spent in the collection tanks until the whole batch volume was collected. Therefore, a systematic way of nut water collection along with minimized handling time should be taken into consideration to minimize the initial microbial counts.

The risk of higher microbial contamination when practicing nut water extraction at an open area surrounded by the environment (Table 2) was well supported by significantly higher $(p<0.05)$ bacterial and Y\&M counts detected at $P_{1}$ in Facility II (SM) (Figure 3). Although the king coconut water is subjected to sterilization in Facility II (SM), it is important to maintain hygienic conditions at the primary processing steps with the aim of controlling the initial microbial loads. If not currently practicing, thermal treatment might not be sufficient in destroying the microorganisms associated with the final product. Similarly, Parish et al. [39] reported that the risk of contamination by environmental factors, mainly due to the openness of the factory premises will lead to a final product which is unsafe for human consumption.

Comparatively lower microbial counts were detected at the initial extraction point $\left(P_{1}-P_{2}\right)$ in Facility III $(\mathrm{CW})$, although most operations were done manually. The microbial load would be lower due to lesser possibilities of cross-contamination. Furthermore, coliforms were not detected throughout the process of Facility III (CW), which is a positive indication of the hygienic quality. In contrast, based on visual observations made at the factory premises, the existing hygienic practices were not at a satisfactory level in Facility III (CW). The lowered contamination levels may be due to the smaller batch size and the recent establishment of the process line. It emphasizes the impact of scale/rate of production on microbial contamination on a particular product, as in agreement with Rolle [7].

According to the Canadian Health Guidelines, the maximum permissible levels of aerobic plate counts (APC) of bacteria and $Y \& M$ counts in any ready-to-drink beverage are declared as $<10^{3}-2 \times 10^{5} \mathrm{CFU} / \mathrm{ml}$ and $<10-2 \times 10^{5} \mathrm{CFU} /$ $\mathrm{ml}$, respectively [40]. However, APC and Y\&M counts of all tested thermally processed king coconut water among all three factories studied in this research ranged between $<1-10^{2} \mathrm{CFU} / \mathrm{ml}$ and $<1-10^{3} \mathrm{CFU} / \mathrm{ml}$, respectively. It was reported that the $\mathrm{Y} \& \mathrm{M}$ counts after pre-heat treatment at Facility III (CW) have been exceeded the permissible levels, although the counts have been receded after scheduled thermal treatment.

Apart from common bacterial and fungal counts, total coliforms and E. coli counts were taken into consideration to assess the potential risk of the occurrence of spoilage and 


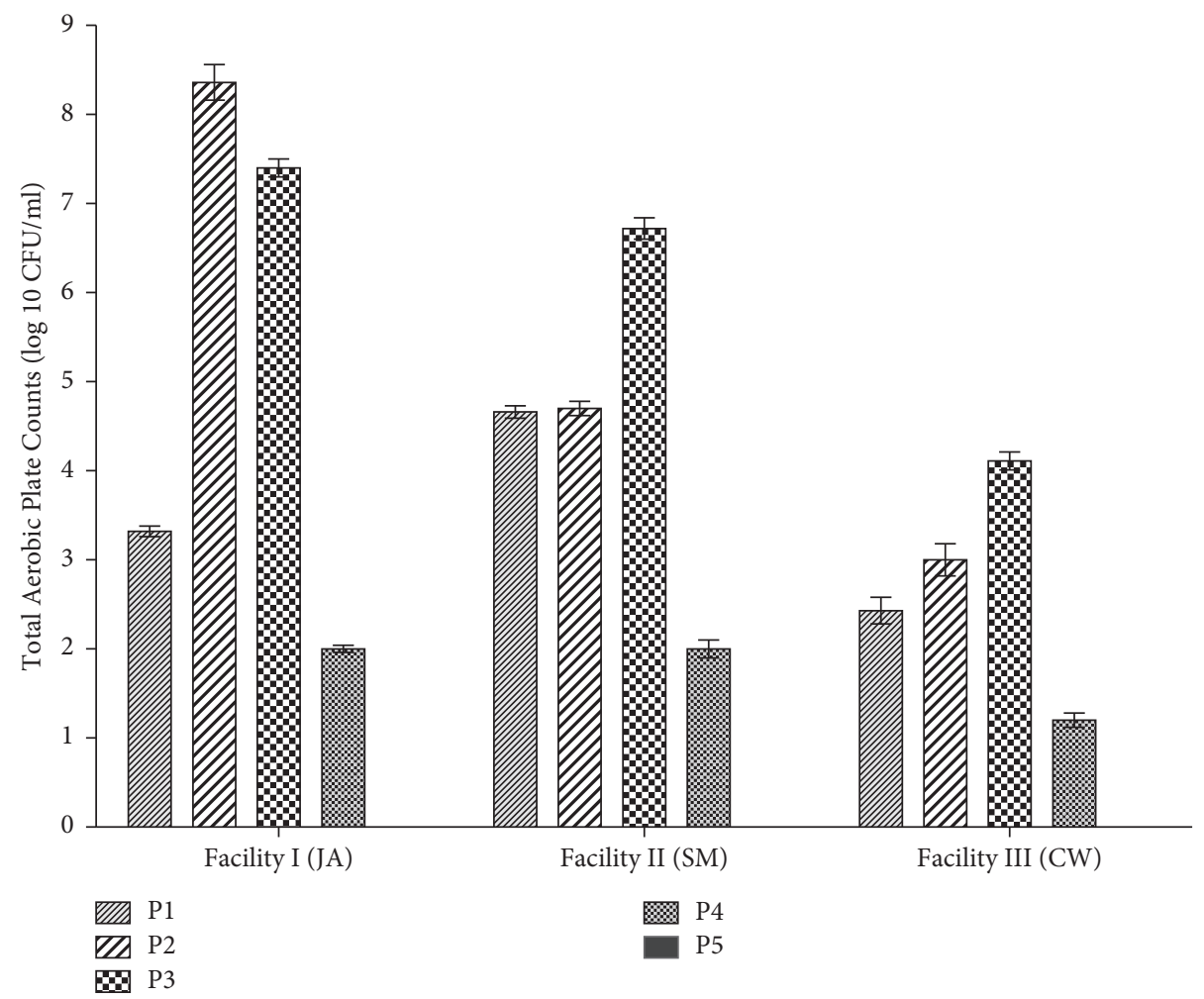

Figure 2: The total aerobic plate count among sampling points at each processing facility. Pre-identified five different sampling points are denoted as $P_{1}, P_{2}, P_{3}, P_{4}$, and $P_{5}$, respectively; Three studied processing facilities are denoted as JA, SM, and CW. Error bars indicate SD.

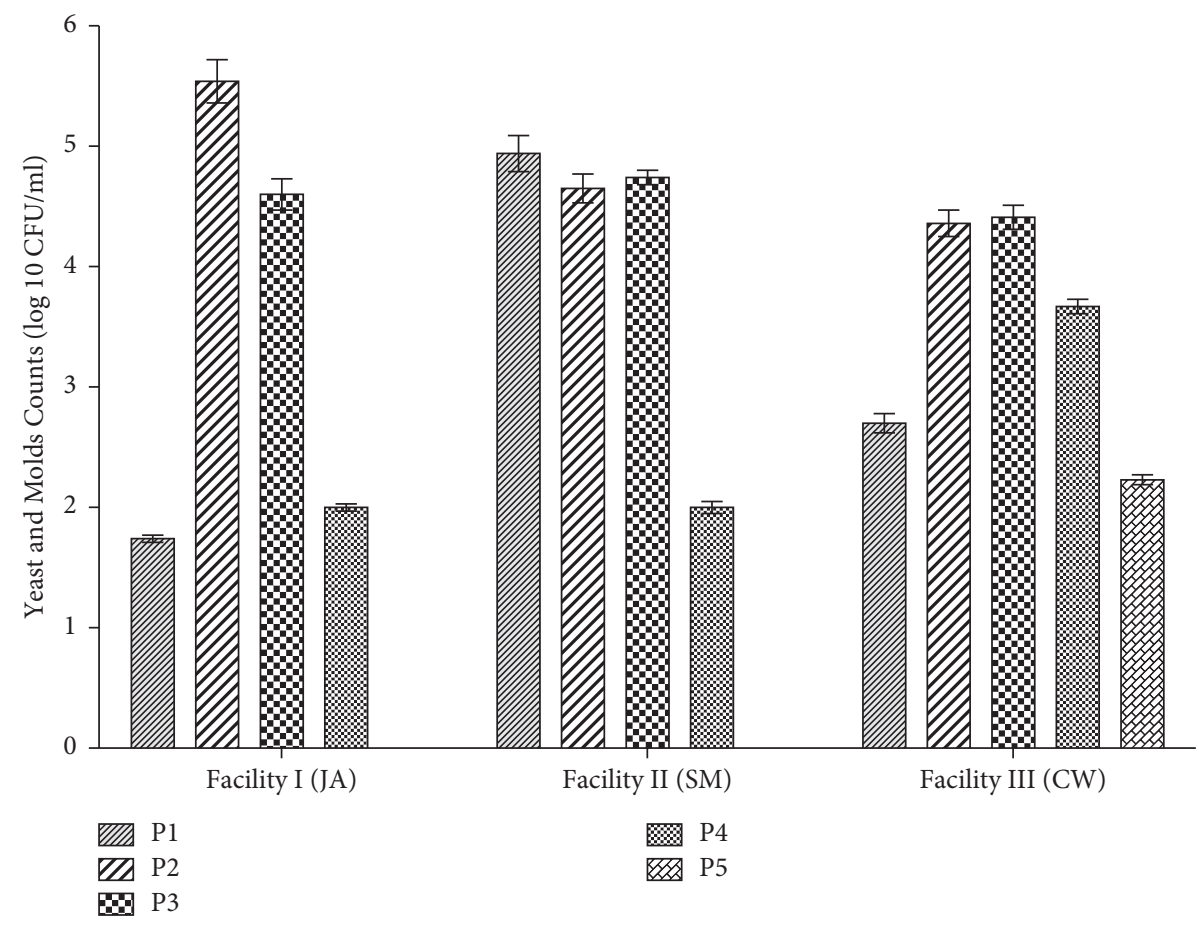

FIGURE 3: Yeast and moulds counts among sampling points at each processing facility. Pre-identified five different sampling points are denoted as $P_{1}, P_{2}, P_{3}, P_{4}$, and $P_{5}$, respectively; Three studied processing facilities are denoted as JA, SM, and CW. Error bars indicate SD. 
TABLE 4: Coliforms and E. coli counts at different sampling points in three factory premises.

\begin{tabular}{lccc}
\hline Factory ID & Sampling points & Coliforms (MPN/ml) & E. coli (MPN/ml) \\
\hline & $P_{1}$ & $>110$ & $>110$ \\
Facility I (JA) & $P_{2}$ & $>110$ & $>110$ \\
& $P_{3}$ & $>110$ & $>110$ \\
& $P_{4}$ & $>110$ & $0.0^{a}$ \\
& $P_{5}$ & $>110$ & $0.4^{a}$ \\
& $P_{1}$ & $>110$ & $0.0^{c}$ \\
Facility II (SM) & $P_{2}$ & $>110$ & $24.0^{a}$ \\
& $P_{3}$ & $>110$ & $2.3^{b}$ \\
& $P_{4}$ & $0.0^{c}$ \\
Facility III (CW) & $P_{5}$ & $0.0^{c}$ \\
& $P_{1}$ & $0.31^{a}$ & $0.0^{a}$ \\
& $P_{2}$ & $0.0^{b}$ & $0.0^{b}$ \\
& $P_{3}$ & $0.0^{b}$ & $0.0^{a}$ \\
& $P_{4}$ & $0.0^{b}$ & $0.0^{a}$ \\
& $P_{5}$ & $2.31^{a}$ & $0.0^{a}$ \\
\hline
\end{tabular}

Data are expressed as MPN/ml calculated based on ISO 4831:2006 (E). Significant difference $(p<0.05)$ within a column for each group of microorganisms was denoted by lowercase letters. Three studied king coconut water processing facilities are denoted as Facility I (JA), Facility II (SM), and Facility III (CW). Pre-identified five different sampling points are denoted as $P_{1}$, nut water extraction; $P_{2}$, bulk collection; $P_{3}$, acidification; $P_{4}$, pre-heat treatment; $P_{5}$, sterilization/pasteurization, respectively. The value "> 110 " refers to "greater than upper limit of detection" in the MPN table.

pathogenic microorganisms in king coconut water (Table 4). Total coliforms among sampling points at Facility I (JA) have been reported as "greater than the upper detection limit" as per the MPN Table (Table 4). In contrast, Facility II (SM) has shown initially higher quantities along with gradually decreasing coliform and $E$. coli counts at $P_{5}$. Interestingly, Facility III (CW) has shown no colonies of coliforms or E. coli from $P_{1}-P_{4}$, while showing a significant increase $(p<0.05)$ at $P_{5}$, which may have led by bottle contamination.

However, it was evident that there is a potential risk of having coliforms even in the thermally processed final product in all three processing facilities. As per the Canadian Health Guidelines [41], the maximum permissible limit of coliforms and $E$. coli ranged between 3 and $10^{3} \mathrm{MPN} / \mathrm{ml}$ and it is clearly evident that the reported counts in thermally processed king coconut water at Facility I (JA) have exceeded the maximum threshold limit. Therefore, it is important to focus on minimizing the microbial counts below the permissible levels.

In consideration of $E$. coli, Facility III (CW) has not shown any evidence of the occurrence of $E$. coli throughout its process line. In contrast, significantly higher $(p<0.05)$ counts have been detected at $P_{1}-P_{3}$ in Facility I (JA), while controlling it successfully at $\left(P_{5}\right)$ via thermal treatment. However, Facility II (SM) has shown considerable counts at the intermediate points and has completely inhibited at $P_{4}-P_{5}$. Results emphasized that the king coconut has a higher chance of getting contaminated with a range of microorganisms along with its preferable food matrix, nutrient availability, and other favored intrinsic conditions as in agreement with International Commission on Microbiological Specifications for Foods (ICMSF) [42]. Although the results have shown significant inhibition $(p<0.05)$ of microbial counts after thermal treatment, it is important to understand the potential risks and thereby the need to implement corrective actions to minimize all possible contaminations along the process lines.
Overall, it was evident that higher microbial loads are more prone to accumulate in excessive bulking processes and prolonged production periods, giving enough time for microbial multiplication before thermal treatment $[6,43]$. Several studies have reported similar findings on residential surface microorganisms persisting on food processing plants and handling surfaces mainly as "biofilms" and evidence of co/cross-resistance to sanitizing agents, which pose a greater threat to human infections after consumption of thermally processed/packed food products [44, 45].

Research studies have reported that several factors, such as equipment surfaces, personnel hands, and processing water are major sources of contamination in food processing plants and may transmit through knives, slicers, conveyor belts, or floors, and panels [46] as similarly evidenced by the present study. Troller [47] reported that a minimum level of $0-10 \mathrm{CFU} / \mathrm{cm}^{2}$ should be achievable after regular cleaning and disinfection routines at processing surfaces. Although it was reported that most of the microorganisms isolated from food processing plants are nonpathogenic, they may have the ability to cause negative effects on the quality of the final product [48]. Therefore, it is suggested that the cleaning and disinfection protocols should be designed in a way to achieve at least a level of microbial inhibition/reduction equal to the daily accumulation of bacterial load in order to control introducing organisms into the processing plant [45]. Subsequently, daily monitoring of "total counts" as a measure of residential bacteria or background flora is vitally important as verification of effective cleaning at food processing plants [49].

Therefore, it is important to have a closed processing environment followed by GMP and GHP to ensure minimized contamination along the production process [50]. King coconut water bottling process is mainly compromised with nut water extraction, water collection and bulking, standardization, hot filling, and pasteurization/sterilization, and it is vitally important to manage these stages to ensure the quality and safety of the final product. 
3.4. Isolation and Identification of Microorganisms. A total of 30 different microbial species (11 bacteria, 10 yeasts, and 9 moulds) have been identified at the molecular level and deposited in NCBI GenBank (Table 5). In consideration of the identified total microbial population in the present study, $74.4 \%$ were bacterial species and $25.6 \%$ were fungal species. Out of all identified bacterial species, the majority were Gram-negative rod-shaped (59.1\%) bacteria and a few Gram-positive cocci (5.4\%) were also identified. More importantly, $11.8 \%$ of Gram-negative cocci, which are known to be highly pathogenic, were also reported mainly in the initial processing steps $\left(P_{1}-P_{2}\right)$. In terms of microorganisms that survived in the thermally processed final product, $44.5 \%$ of them were bacterial species and yeast and moulds were accounted for $33.3 \%$ and $22.2 \%$, respectively. Based on the literature [48], 54.5\% of the identified bacterial species can be categorized as opportunistic pathogens and $82.3 \%$ of fungal species were spoilage microorganisms.

Pantoea dispersa, Bacillus siamensis, Pseudomonas stutzeri, and Acinetobacter lactucae were detected as the most prominent bacterial species that have survived in thermally processed king coconut water in the present study. According to the literature, these species are known to be facultative anaerobes and opportunistic pathogens, which cause numerous infections in humans and quality deterioration in the processed product $[51,52]$. Pantoea spp. has been reported to cause other infections, including respiratory infections, neonatal sepsis, and bloodstream infections [53]. A. lactucae and B. siamensis have been reported as spoilage microorganisms due to their ability to metabolize diverse carbon sources aerobically or anaerobically [54]. Pseudomonas spp. is commonly reported in causing infections in the urinary tract, central nervous system, and musculoskeletal system [55]. However, C. botulinum, C. pasteurianum, E. coli O157:H7, Salmonella spp., Listeria spp., and Shigella spp. are commonly identified spoilage and pathogenic microorganisms in thermally processed fruit juices [56], which were not found in the present study.

The frequent occurrence of Pseudomonas spp. in food processing plants as detected in this research is well supported by several research studies $[38,45]$. It was reported that a few major groups/genera such as Pseudomonas, Acinetobacter, and Enterobacteriaceae were found to have the highest prevalence in food processing plants [57]. Furthermore, it was reported that Gram-negative bacteria have dominated over Gram-positive bacteria when all types of food industries were taken together as similarly reported by the present research work [57].

Moreover, yeast and mould isolates such as Pichia kudriavzevii, Debaryomyces nepalensis, Candida carpophila, Penicillium citrinum, Microdochium fisheri, and Trichosporon asahii have survived in thermally processed king coconut water. It was reported that Pichia spp. and Trichosporon spp. are commonly associated with human skin/hair [58] and the presence of these species at Facility III (CW) was well supported as it is highly equipped with manual operations. Similarly, Candida krusei, Saccharomyces bisporus, and Pichia membranifaciens have been reported as major sources affecting the stability of "acidified foods" [59].
Furthermore, Lawlor et al. [60] reported that dominant moulds recorded in acidified foods/fruit juices belong to Penicillium spp., Cladosporium spp., Aspergillus spp., and Botrytis spp., while some of them were known to produce mycotoxins, such as byssochlamic acid, patulin, ochratoxin, and citrinin [61]. Possible contaminations due to piling up nuts on the bare floor and nut water extraction without nut washing were well confirmed by the detection of Acremonium pinkertoniae (S62) and Geotrichum candidum (S68) at Facility II (SM) as they were commonly found in soil/ decaying vegetation [48]. These findings emphasized that species identification studies were well aligned with the key observations made at the facility survey.

Apart from the microorganisms that survived in the thermally processed finished product, several other potential food-borne pathogens were also detected, such as Klebsiella pneumoniae, Escherichia fergusonii, and Enterobacter kobei (Table 5). Similar results were reported by Adolf et al. [62], claiming that E. coli and K. pneumoniae growth was observed in fresh king coconut water with a contamination level of $>2.83 \times 10^{8} \mathrm{CFU} / \mathrm{ml}$. Potential risks associated with Enterobacteriaceae spp. in commercially processed fruit juices/beverages have been discussed by the Ogodo et al. [51], declaring that poor sanitation, extraction, raw-material contamination, lack of heat sterilization, and inadequate quality control during processing could be contributory factors to the presence of these organisms.

In addition, "prodigiosin" (red pigment) producing Serratia rubidaea [63] was detected in king coconut bulk tanks at Facility II (SM). Similarly, isolation of S. rubidaea from spoiled coconut water was reported by Siva et al. [64] and the production of red pigment may have an influence on "pink discolouration" of king coconut water, which is a serious quality concern at present. Several research studies have also confirmed the presence of Serratia spp. in coconut water and further studies on the metabolic pathways of these organisms will be helpful for the coconut water processing industry $[63,64]$.

3.5. Phylogenetic Analyses. Evolutionary relationships among all identified microorganisms were assessed using phylogenetic analyses [58]. Comparison with a reference database (NCBI) containing the sequences of all type strains of bacteria and fungi showed that the isolated bacterial strains of the present study were closely related to the species of phyla Proteobacteria and Firmicutes (Figure 4), while all fungal strains belonged to the divisions Ascomycota and Basidiomycota (Figure 5).

All strains of Pantoea, Serratia, Klebsiella, Enterobacter, Acinetobacter, Pseudomonas, and Bacillus were clustered with their respective type strains (NR), whereas E. fergusonii (J31) and E. kobei (S51) each formed a single branch close to E. coli and E. roggenkampii, respectively (Figure 4). All isolated strains of $B$. siamensis were closely related to $B$. subtilis, whereas the type strain of B. cereus was formed a single branch in the cluster of "Order Bacillales." Furthermore, none of the isolates were clustered with "Order 
TABLE 5: King coconut water-associated microorganisms identified in this study with respective GenBank accession numbers.

\begin{tabular}{|c|c|c|c|c|c|c|c|c|}
\hline \multicolumn{3}{|c|}{ Bacterial species } & \multicolumn{3}{|c|}{ Yeasts species } & \multicolumn{3}{|c|}{ Moulds species } \\
\hline $\begin{array}{l}\text { Isolate } \\
\text { ID }\end{array}$ & $\begin{array}{l}\text { Genus/species } \\
\text { identification }\end{array}$ & $\begin{array}{l}\text { Accession } \\
\text { number }\end{array}$ & $\begin{array}{l}\text { Isolate } \\
\text { ID }\end{array}$ & $\begin{array}{l}\text { Genus/species } \\
\text { identification }\end{array}$ & $\begin{array}{l}\text { Accession } \\
\text { number }\end{array}$ & $\begin{array}{l}\text { Isolate } \\
\text { ID }\end{array}$ & $\begin{array}{l}\text { Genus/species } \\
\text { identification }\end{array}$ & $\begin{array}{c}\text { Accession } \\
\text { number }\end{array}$ \\
\hline J19 & $\begin{array}{c}\text { Klebsiella } \\
\text { pneumoniae }\end{array}$ & MT826212 & J06 & Candida orthopsilosis & MT875261 & S14 & $\begin{array}{l}\text { Quambalaria } \\
\text { simpsonii }\end{array}$ & MT879594 \\
\hline $\mathrm{J} 30$ & Pantoea dispersa & MT826213 & $\mathrm{J} 11$ & Candida carpophila & MT875268 & S15 & $\begin{array}{l}\text { Pestalotiopsis } \\
\text { adusta }\end{array}$ & MT879595 \\
\hline $\mathrm{J} 31$ & $\begin{array}{l}\text { Escherichia } \\
\text { fergusonii }\end{array}$ & MT826214 & S60 & Candida boidinii & MT875270 & S62 & $\begin{array}{l}\text { Acremonium } \\
\text { pinkertoniae }\end{array}$ & MT879596 \\
\hline $\mathrm{J} 34$ & $\begin{array}{l}\text { Enterobacter } \\
\text { roggenkampii }\end{array}$ & MT826215 & C09 & $\begin{array}{l}\text { Wickerhamomyces } \\
\text { anomalus }\end{array}$ & MT875242 & S63 & Cosmospora butyri & MT879597 \\
\hline $\mathrm{J} 35$ & $\begin{array}{l}\text { Enterobacter } \\
\text { roggenkampii }\end{array}$ & MT826216 & $\mathrm{C} 10$ & $\begin{array}{l}\text { Wickerhamomyces } \\
\text { anomalus }\end{array}$ & MT875243 & S67 & Fusarium striatum & MT879643 \\
\hline S07 & $\begin{array}{l}\text { Enterobacter } \\
\text { roggenkampii }\end{array}$ & MT826221 & $\mathrm{C} 13$ & Candida parapsilosis & MT875249 & S68 & $\begin{array}{l}\text { Geotrichum } \\
\text { candidum }\end{array}$ & MT890144 \\
\hline S30 & Bacillus siamensis & MT826223 & $\mathrm{C} 28$ & Trichosporon asahii & MT875250 & S69 & $\begin{array}{l}\text { Penicillium } \\
\text { sclerotiorum }\end{array}$ & MT892770 \\
\hline S35 & Bacillus siamensis & MT826225 & & & & S70 & $\begin{array}{l}\text { Penicillium } \\
\text { citrinum }\end{array}$ & MT890157 \\
\hline S38 & Pantoea dispersa & MT826230 & & & & $\mathrm{C} 11$ & $\begin{array}{c}\text { Cladosporium } \\
\text { halotolerans }\end{array}$ & MT875274 \\
\hline S46 & Pantoea dispersa & MT826239 & & & & $\mathrm{C} 16$ & $\begin{array}{c}\text { Penicillum } \\
\text { citrinum }\end{array}$ & MT875277 \\
\hline S51 & Enterobacter kobei & MT826240 & & & & $\mathrm{C} 30$ & $\begin{array}{l}\text { Microdochium } \\
\quad \text { fisheri }\end{array}$ & MT875317 \\
\hline S52 & Serratia rubidaea & MT826241 & & & & $\mathrm{C} 44$ & $\begin{array}{l}\text { Penicillum } \\
\text { citrinum }\end{array}$ & MT875320 \\
\hline $\mathrm{C} 08$ & Bacillus siamensis & MT804636 & & & & C51 & $\begin{array}{l}\text { Penicillum } \\
\text { citrinum }\end{array}$ & MT880733 \\
\hline $\mathrm{C} 27$ & $\begin{array}{l}\text { Pseudomonas } \\
\text { stutzeri }\end{array}$ & MT803053 & & & & & & \\
\hline $\mathrm{C} 29$ & $\begin{array}{l}\text { Oceanobacillus } \\
\text { kimchii }\end{array}$ & MT798808 & & & & & & \\
\hline C31 & Bacillus nealsonii & MT798809 & & & & & & \\
\hline $\mathrm{C} 33$ & Bacillus siamensis & MT798812 & & & & & & \\
\hline C35 & $\begin{array}{l}\text { Pseudomonas } \\
\text { stutzeri }\end{array}$ & MT798814 & & & & & & \\
\hline $\mathrm{C} 40$ & $\begin{array}{l}\text { Pseudomonas } \\
\text { stutzeri }\end{array}$ & MT804629 & & & & & & \\
\hline
\end{tabular}

The letters J, S, and C refers to king coconut processing Facility I (JA), Facility II (SM), and Facility III (CW), and Isolate ID is given in a format showing processing facility followed with isolate number accordingly.

Clostridiales" containing Clostridium spp., which is considered in thermal process validation of LACF by the FDA.

In terms of the phylogenetic tree of fungal strains, two monophyletic clades were formed representing "Division Ascomycota." One clade consisted of a broader range of fungal species closely related to Orders Eurotiales, Capnodiales, Xylariales, and Hypocreales, while the other clade is clustered with species belonging to Order Saccharomycetales (Figure 5). Fungal strains of S14 and C28 were clustered separately as belonging to the "Division Basidiomycota." Isolate C51 (MT880733) was clustered together with P. citrinum and isolate S69 (MT892770) was clustered (100\%) together with the type strain of $P$. sclerotiorum in a sister clade of $P$. citrinum. Furthermore, isolates S15 (MT879595), S62 (MT879596), and S68 (MT890144) were initially identified as species belonging to the family Sporocadaceae (Pestalotiopsis spp.), family Bionecteriaceae, and order Saccharomycetales, respectively. However, isolates S15, S62, and S68 were further identified up to the species level with a comparison of reference gene sequences based on the BLAST hits as Pestalotiopsis adusta (100\%), Acremonium pinkertoniae (97\%), and Geotrichum candidum (100\%), respectively. Isolates Q50 (MT875254) and J11 (MT875268) have been clustered together with Meyerozyma carpophila with a bootstrap value of $100 \%$ within the same clade.

Phylogenetic analyses of all isolated bacterial and fungal strains of this study highlighted that the species belonging to the families Enterobacteriaceae and Pseudomonadaceae were the most prominent bacterial species associated with king coconut water. In contrast, fermentative yeast strains belonging to the Saccharomycetaceae were the most found fungal species in king coconut water.

In summary, king coconut water is relish produce, which is sterile within the nut and more potent to undergo rapid spoilage and quality deterioration whenever exposed to the environment. Therefore, proper handling, sanitation, 


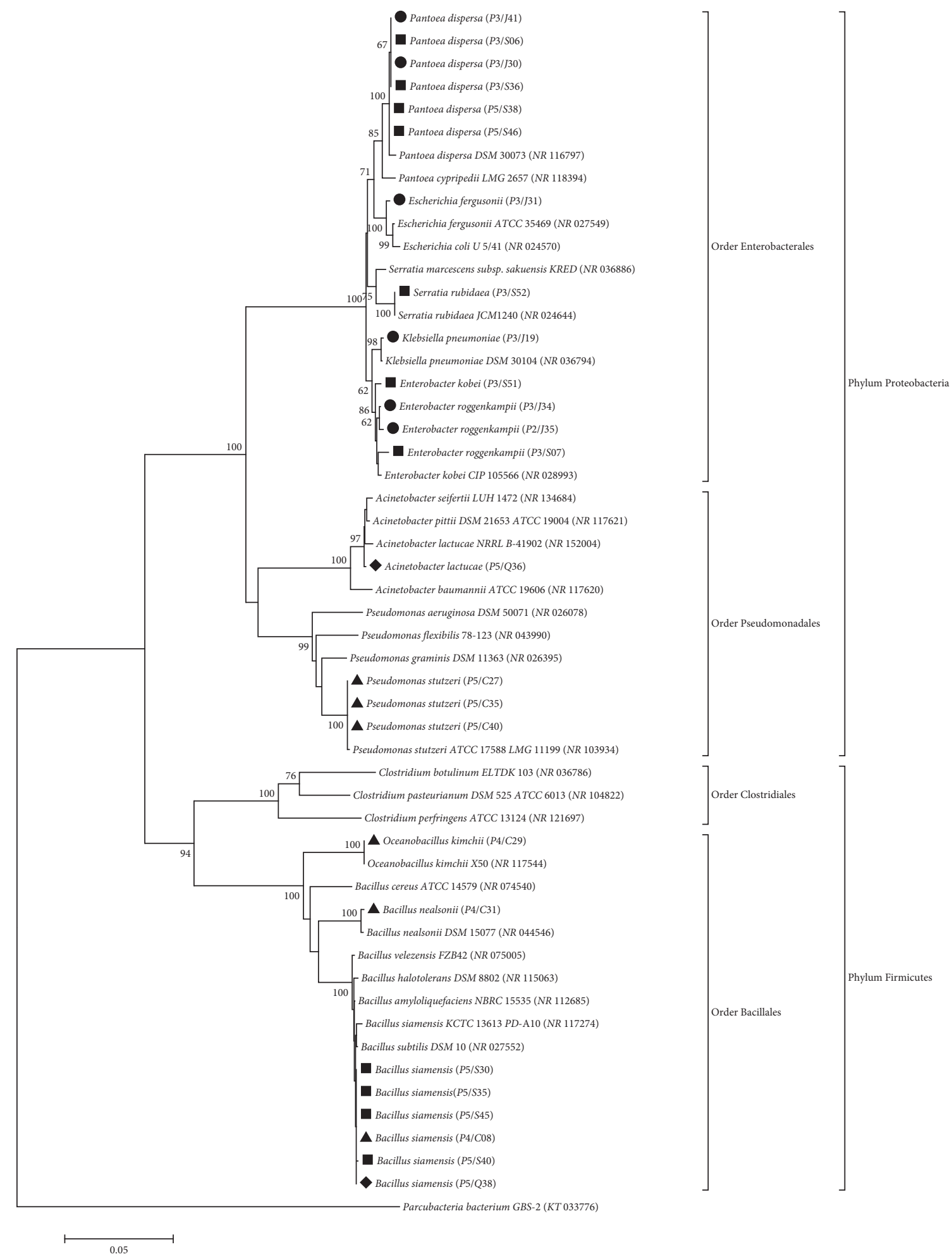

FIgURE 4: Phylogenetic tree of bacteria isolated from king coconut water processing facilities based on their 16S rRNA gene sequences. The strains isolated in this study are given in bold italics with isolation point and isolate ID. Each symbol denoted the following: $\bullet$ Facility I (JA), - Facility II (SM), $\boldsymbol{\Delta}$ Facility III (CW), and $\diamond$ quality-defected samples, respectively. The tree was constructed using the neighbor-joining method with MEGA 7. The percentages of bootstrap values for 1000 replicates are indicated at the branching point. The scale bar indicates changes per position. 


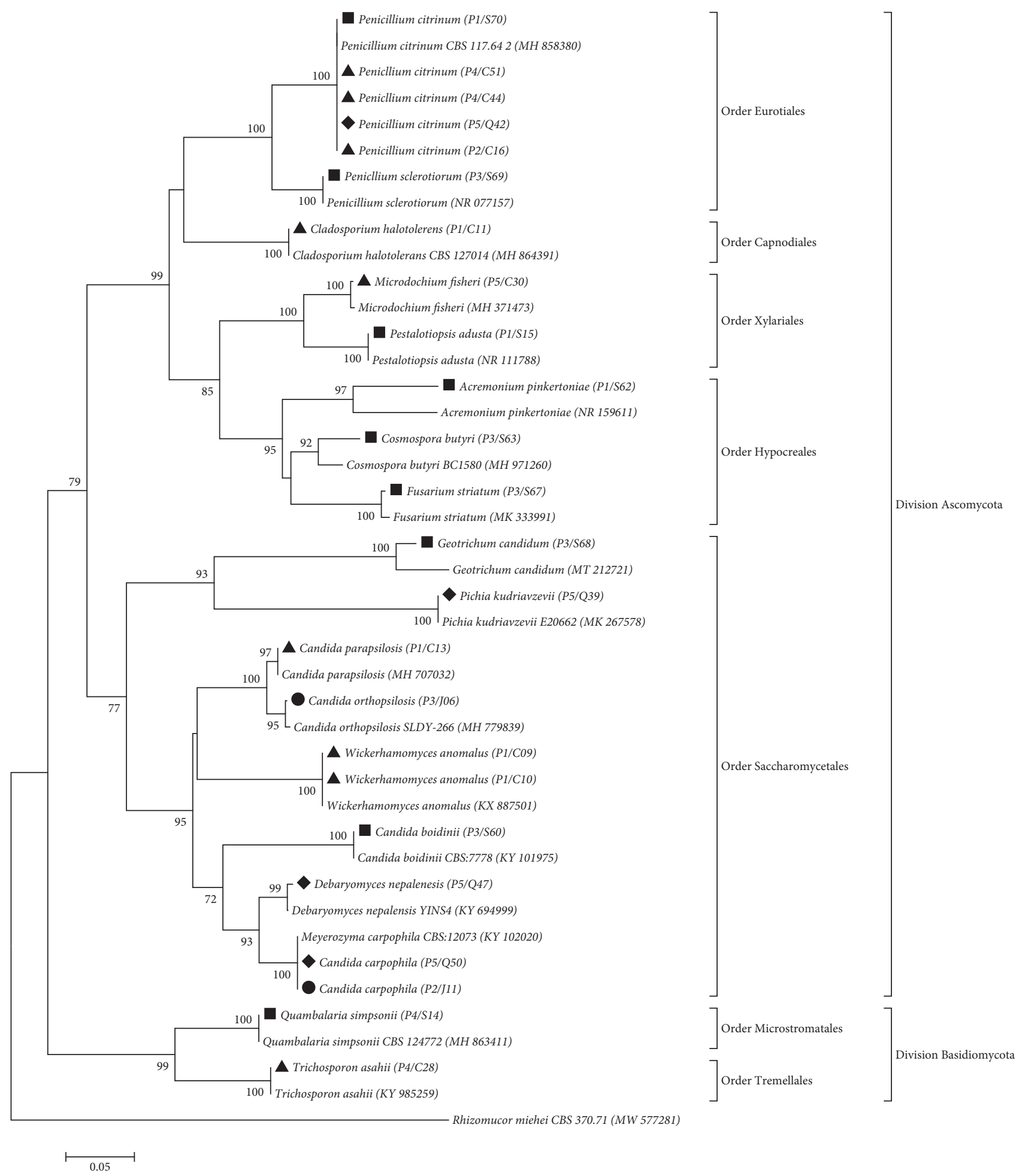

FIGURE 5: Phylogenetic tree of fungi (yeasts and moulds) isolated from king coconut water processing facilities based on their ITS1 and ITS2 gene sequences. The strains isolated in this study are given in bold italics with isolation point and isolate ID. Each symbol denoted the following: Facility I (JA), - Facility II (SM), $\boldsymbol{\Delta}$ Facility III (CW), and $\bullet$ quality-defected samples, respectively. The tree was constructed using the neighbor-joining method with MEGA 7. The percentages of bootstrap values for 1000 replicates are indicated at the branching point. The scale bar indicates changes per position.

hygiene, and temperature management are essential to retaining the wholesomeness of the product until the final step in processing. The risk of possible contamination could be avoided through effective cleaning and disinfection procedures, reception of clean raw materials, improved personal hygiene, proper waste management, and well- 
designed factory layouts with separated processing areas. Potential microbial contaminations due to inappropriate operational and manufacturing processes at the studied processing facilities have been clearly addressed in the present study and the real need for the implementation and verification of GMP/GHP procedures at the food processing plant has been highlighted. Since this study was limited only to three leading king coconut water processing factories in Sri Lanka, further confirmation studies should be done covering a higher number of processing facilities for further precise findings. Identification based on metagenomics is suggested for comprehensive results and studies on thermal inactivation kinetics for the identified microorganisms will be a timely requirement.

\section{Conclusions}

King coconut water undergoes significant changes in $\mathrm{pH}$, TSS, sugars, and colour during processing and it is necessary to follow immediate processing while avoiding excessive holding at intermediate steps before thermal processing to preserve the natural organoleptic properties of the product. The enumeration study revealed that significantly higher microbial loads have been introduced to the processing line at intermediate processing steps and it is important to pay attention on frequent clean-in-place and sanitation practices to minimize the risk of contamination. Since king coconut water is relatively high in $\mathrm{pH}$, TSS, and water activity, it provides an excellent environment for the growth of a wide array of both spoilage and pathogenic microorganisms. However, it was evident that opportunistic pathogens have survived even after the thermal treatment in king coconut water bottling processes and the thermal process should be well focused on those microorganisms with precise knowledge on their epidemiology, pathogenicity, thermal resistance, and acid adaptation, including metabolic pathways. Therefore, it is important to pay attention to controlling possible contamination via adherence to GHP/GMP with minimized handling time. Results suggested that the thermal process of bottled king coconut water at the studied processing facilities should be validated with revealed knowledge on potential hazardous microorganisms while preserving its sensory attributes.

\section{Data Availability}

Data will be made available on request to the corresponding author.

\section{Conflicts of Interest}

The authors declare that there are no conflicts of interest regarding the publication of this work.

\section{Acknowledgments}

This work was supported by the Industrial Technology Institute, Sri Lanka (Grant no. TG 19/173).

\section{References}

[1] Coconut Development Authority, Export Data-Export Performance of Food and Beverage Sector, Sri Lanka, Sri Lanka Export Development Board, Colombo, Sri Lanka, 2020, https://www.cda.gov.lk/web/images/pdf/\%20export_perfo/ 2020/DEC_T1.pdf.

[2] M. N. Shubhashree, G. Venkateshwarlu, and S. H. Doddamani, "Therapeutic and nutritional values of Narikelodaka (tender coconut water)-a review," Research Journal of Pharmacognosy and Phytochemistry, vol. 6, no. 4, pp. 195-201, 2014.

[3] J. W. Yong, L. Ge, Y. F. Ng, and S. N. Tan, "The chemical composition and biological properties of coconut (Cocos nucifera L.) water," Molecules, vol. 14, no. 12, pp. 5144-5164, 2009.

[4] Code of Federal Regulation, 21 CFR: Part 113, "Thermally Processed Low-Acid Foods Packaged in Hermetically Sealed Containers, Food and Drug Administration, USA, 2021, https://www.accessdata.fda.gov/scripts/cdrh/cfdocs/cfcfr/ CFRSearch.\%20cfm?CFR\%20Part=113\&showFR=1.

[5] Code of Federal Regulation, 21 CFR: Part 114, "Acidified Foods, Food and Drug Administration, United States, 2021, https://www.accessdata.fda.gov/scripts/cdrh/cfdocs\%20/ cfcfr/CFRSearch.cfm?CFRPart=114\&showFR=1.

[6] F. H. Barron, Acid, Acidified and Low-acid Foods Canning Guidelines for Food Processors. Bulletin EC 705, Clemson: Food Nutrition and Packaging Science Department, Clemson University, Clemson, SC, USA, 2000.

[7] R. Rolle, "Good practice for the small-scale production of bottled coconut water," Agricultural and Food Engineering Training and Resource Materials, p. 35, Food and Agriculture Organization, Rome, Italy, 2007.

[8] D. H. Brainard, "Color appearance and color difference specification," The Science of Colorpp. 191-216, Elsevier Science Publishers Ltd, Barking, UK, 2nd edition, 2003.

[9] K. D. P. P. Gunathilake, "Optimum physico-chemical and processing parameters for the preservation of king coconut Water," CORD, vol. 28, no. 1, pp. 8-10, 2012.

[10] ISO 10504, Starch Derivatives-Determination of the Composition of Glucose Syrups, Fructose Syrups and Hydrogenated Glucose Syrups-Method Using High-Performance Liquid Chromatography, International Organization for Standardization, Geneva, Switzerland, 2013.

[11] ISO 4833-1, Methods of Test for Microbiology of Food and Animal Feeding Stuffs - Horizontal Method for the Enumeration of Microorganisms - Colony Count at $30^{\circ} \mathrm{C}$ by the Pour Plate Technique, International Organization for Standardization, Geneva, Switzerland, 2013.

[12] ISO 21527-1, Methods of Test for Microbiology of Food and Animal Feeding Stuffs-Horizontal Method for the Enumeration of Yeasts and Moulds-Colony Count Technique in Products with Water Activity Greater than 0.95, International Organization for Standardization, Geneva, Switzerland, 2013.

[13] ISO 4831, Methods of Test for Microbiology of Food and Animal Feeding Stuffs-Horizontal Method for the Detection and Enumeration of Coliform-Most Probable Number Technique, International Organization for Standardization, Geneva, Switzerland, 2006.

[14] ISO 7251, Methods of Test for Microbiology of Food and Animal Feeding Stuffs - Horizontal Method for the Detection and Enumeration of Presumptive Escherichia coli-Most Probable Number Technique, International Organization for Standardization, Geneva, Switzerland, 2005. 
[15] D. H. Bergey, J. G. Holt, and N. R. Krieg, Bergey's Manual of Determinative Bacteriology, Lippincott Williams \& Wilkins, MI, USA, 9th edition, 1994.

[16] R. Coico, "Gram staining," Current Protocols in Microbiology, vol. 1, no. 1, pp. 31-35, 2006.

[17] T. J. Mackie, J. G. Collee, T. J. Mackie, and J. E. McCartney, Mackie and McCartney Practical Medical Microbiology, Churchill Livingstone, New York, NY, USA, 14th edition, 1996.

[18] E. R. B. Moore, A. Arnscheidt, A. Krüger, C. Strömpl, and M. Mau, "Simplified protocols for the preparation of genomic DNA from bacterial cultures," Molecular Microbial Ecology Manual, vol. 1, no. 1, pp. 1-15, 1999.

[19] S. Aamir, S. Sutar, S. K. Singh, and A. Baghela, "A rapid and efficient method of fungal genomic DNA extraction, suitable for PCR based molecular methods," Plant Pathology \& Quarantine, vol. 5, no. 2, pp. 74-81, 2015.

[20] J. A. Frank, C. I. Reich, S. Sharma, J. S. Weisbaum, B. A. Wilson, and G. J. Olsen, "Critical evaluation of two primers commonly used for amplification of bacterial $16 \mathrm{~S}$ rRNA genes," Applied and Environmental Microbiology, vol. 74, no. 8, pp. 2461-2470, 2008.

[21] G. James, "Universal bacterial identification by PCR and DNA sequencing of 16S rRNA gene," in PCR for Clinical Microbiology, pp. 209-214, Springer, Dordrecht, Netherlands, 2010.

[22] K. J. Martin and P. T. Rygiewicz, "Fungal-specific PCR primers developed for analysis of the ITS region of environmental DNA extracts," BMC Microbiology, vol. 5, no. 28, pp. 28-11, 2005.

[23] K. Tamura, D. Peterson, N. Peterson et al., "MEGA5: molecular evolutionary genetics analysis using maximum likelihood, evolutionary distance, and maximum parsimony methods," Molecular Biology and Evolution, vol. 28, no. 10, pp. 2731-2739, 2011.

[24] B. D. Nikunjkumar, Molecular identification of bacteria using 16s rDNA sequencing, Ph.D thesis, Gujarat University, Gujarat, India, 2012.

[25] N. Saitou and M. Nei, "The neighbor-joining method: a new method for reconstructing phylogenetic trees," Molecular Biology and Evolution, vol. 4, no. 4, pp. 406-425, 1987.

[26] M. Nei and S. Kumar, Molecular Evolution and Phylogenetics, Oxford University Press, New York, NY, USA, 2000.

[27] M. G. F. Chowdhury, M. M. Rahman, A. F. M. T. Islam, and M. S. Islam, "Processing and preservation of green coconut water," Journal of Innovation and Development Strategy, vol. 2, no. 3, pp. 21-25, 2009.

[28] E. Jansz, C. Rabel, and F. Marikar, "Some factors affecting the development of pink colour in coconut water," Journal of the National Science Foundation of Sri Lanka, vol. 20, no. 1, pp. 107-113, 1992.

[29] N. D. Ediriweera, "King coconut," Cordulia, vol. 12, no. 2, p. 34, 1996.

[30] J. C. Jackson, A. Gordon, G. Wizzard, K. McCook, and R. Rolle, "Changes in chemical composition of coconut (Cocos nucifera) water during maturation of the fruit," Journal of the Science of Food and Agriculture, vol. 84, no. 1, pp. 1049-1052, 2004.

[31] N. A. M. Eskin, Biochemistry of Food Processing: Browning Reaction in Foodspp. 69-145, Academic Press, San Diego, CA, USA, 2nd edition, 1990.

[32] L. F. Abreu and J. D. A. F. Fariai, "Temperature and ascorbic acid effects in physico-chemical stability and enzymatic activity of coconut water (Cocos nucifera L.) aseptic filled," Journal of Food Science \& Technology, vol. 27, no. 2, pp. 226-232, 2007.
[33] S. Da, A. Lima, G. A. Maia, P. H. M. De Sousa, G. M. Do Prado, and S. Rodrigues, "Storage stability of a stimulant coconut water-acerola fruit juice beverage," International Journal of Food Science and Technology, vol. 44, no. 7, pp. 1445-1451, 2009.

[34] J. M. Carvalho, G. A. Maia, R. W. Figueiredo, E. S. Brito, and S. Rodrigues, "Storage stability of a stimulant coconut watercashew apple beverage," Journal of Food Processing and Preservation, vol. 31, no. 1, pp. 178-189, 2007.

[35] O. P. Chauhan, B. S. Archana, A. Singh, P. S. Raju, and A. S. Bawa, "A refreshing beverage from mature coconut water blended with lemon juice," Journal of Food Science \& Technology, vol. 51, no. 11, pp. 3355-3361, 2014.

[36] N. Martí, A. Pérez-Vicente, and C. García-Viguera, "Influence of storage temperature and ascorbic acid addition on pomegranate juice," Journal of the Science of Food and Agriculture, vol. 82, no. 2, pp. 217-221, 2001.

[37] V. Kabasakalis, D. Siopidou, and E. Moshatou, "Ascorbic acid content of commercial fruit juices and its rate of loss upon storage," Food Chemistry, vol. 70, no. 2, pp. 325-328, 2000.

[38] D. N. Malavi, T. Muzhingi, and G. O. Abong', "Good manufacturing practices and microbial contamination sources in orange fleshed sweet potato puree processing plant in Kenya," International Journal of Food Science, vol. 2018, Article ID 4093161, 11 pages, 2018.

[39] M. E. Parish, "Coliforms, Escherichia coli and Salmonella serovars associated with a citrus-processing facility implicated in a salmonellosis outbreak $\dagger$," Journal of Food Protection, vol. 61, no. 3, pp. 280-284, 1998.

[40] Health Canada, Health Products and Food Branch (HPFB) Standards and Guidelines for Microbiological Safety of FoodAn Interpretive Summary, Government of Canada, Ottawa, Canada, 2016, https://health-canada/services/food-nutrition/ research-programs-analytical-methods/analytical-methods/ compendium-methods/official-methods\%20microbiologicalanalysis-foods-compendium-analytical-methods.html.

[41] Health Canada, Microbial Guidelines for Ready-to-Eat FoodsA Guide for the Conveyance Industry and Environmental Health Officers (EHO), Government of Canada, Ottawa, Canada, 2013, https://publications.gc.ca/collections/ collection_2014/sc-hc/H164-167-2013-eng.pdf.

[42] ICMSF, Microorganisms in Foods, Kluwer Academic/ Plenum Publishers, New York, NY, USA, 2002.

[43] R. Podolak, G. Black, J. T. Barach, C. Balestrini, D. Howell, and B. Shafer, Canned Foods - Principles of Thermal Process Control, Acidification and Container Closure Evaluation, GMA Science and Education Foundation, Washinton, D.C, USA, 8th edition, 2015.

[44] D. E. Nivens, B. M. Co, and M. J. Franklin, "Sampling and quantification of biofilms in food processing and other environments," in Bifilms in the Food and Beverage Industries, P. M. Fratamico, B. A. Annous, and I. V. Gunther, Eds., Woodhead Publishing Limited, Cambridge, UK, pp. 539-568, 2009.

[45] T. Møretrø and S. Langsrud, "Residential bacteria on surfaces in the food industry and their implications for food safety and quality," Comprehensive Reviews in Food Science and Food Safety, vol. 16, no. 5, pp. 1022-1041, 2017.

[46] R. P. Bates, J. R. Morris, and P. G. Crandall, Principles and Practices of Small-and Medium-Scale Fruit Juice Processing, Food and Agriculture Organization of United Nations, Rome, Italy, 2001.

[47] J. A. Troller, Sanitation in Food Processing, Academic Press, New York, NY, USA, 1st edition, 2012. 
[48] M. E. Parish, N. L. Heredia, I. V. Wesley, and J. S. Garcia, Food safety issues and the microbiology of fruit beverages and bottled water," Microbiologically Safe Foods, pp. 291-304, Willey publishers, New York, NY, USA, 2009.

[49] C. Griffith, "Improving surface sampling and detection of contamination," in Handbook of Hygiene Control in the Food Industry, H. L. M. Lelieveld, M. A. Mostert, and J. Holah, Eds., Wood head publishing, Cambridge, UK, 2005.

[50] F. H. Barron and A. M. Fraser, Acidified Foods: Food Safety Considerations for Food Processors in Food Industry, Innocenzo Muzzalupo, Intech Open, London, UK, 2013.

[51] A. Ogodo, O. Ugbogu, U. Ekeleme, and N. Nwachukwu, "Microbial quality of commercially packed fruit juices in South-East Nigeria," Journal of Basic and Applied Research in Biomedicine, vol. 2, no. 3, pp. 240-245, 2016.

[52] M. D. Kader, A. Munjur, M. D. Mamun, T. Islam, and N. Sultana, "Bacteriological analysis of some commercially packed and fresh fruit juices available in Jessore city: a comparative look," International Journal of Biosciences, vol. 5, no. 1, pp. 415-420, 2014.

[53] N. Asai, Y. Koizumi, A. Yamada et al., "Pantoea dispersa bacteremia in an immune-competent patient: a case report and review of the literature," Journal of Medical Case Reports, vol. 13, no. 1, pp. 1-5, 2019.

[54] A. P. Rooney, C. A. Dunlap, and L. B. Flor-Weiler, "Acinetobacter lactucae sp. nov., isolated from iceberg lettuce (Asteraceae: Lactuca sativa)," International Journal of Systematic and Evolutionary Microbiology, vol. 66, no. 9, pp. 3566-3572, 2016.

[55] N. Bisharat, T. Gorlachev, and Y. Keness, "10-years hospital experience in Pseudomonas stutzeri and literature review," The Open Infectious Diseases Journal, vol. 6, no. 1, pp. 21-24, 2012.

[56] E. Ağçam, A. Akyıldız, and B. Dündar, "Thermal pasteurization and microbial iinactivation of fruit juices," in Fruit Juices, pp. 309-339, Academic Press, Cambridge, MA, USA, 2018.

[57] S. André, F. Zuber, and F. Remize, "Thermophilic sporeforming bacteria isolated from spoiled canned food and their heat resistance. Results of a French ten-year survey," International Journal of Food Microbiology, vol. 165, no. 2, pp. 134-143, 2013.

[58] A. L. Colombo, A. C. B. Padovan, and G. M. Chaves, "Current knowledge of Trichosporon spp. and trichosporonosis," Clinical Microbiology Reviews, vol. 24, no. 4, pp. 682-700, 2011.

[59] M. Stratford, "Food and beverage spoilage yeasts," in Yeasts in Food and Beverages Handbook, G. M. Fleet and A. Querol, Eds., pp. 335-379, Springer, Germany, Berlin, 2006.

[60] K. A. Lawlor, J. D. Schuman, P. G. Simpson, and P. J. Taormina, "Microbiological Spoilage of beverages," in Compendium of the Microbiological Spoilage of Foods and Beverages, W. H. Sperber and M. P. Doyle, Eds., Springer Science Business Media, New York, NY, USA, pp. 245-284, 2009.

[61] N. Delage, A. d'Harlingue, B. Colonna Ceccaldi, G. Bompeix, and G. Bompeix, "Occurrence of mycotoxins in fruit juices and wine," Food Control, vol. 14, no. 4, pp. 225-227, 2003.

[62] K. A. Adolf, D. D. Edna, and A. Rebecca, "Potential bacterial health risk posed to consumers of fresh coconut (Cocos nucifera L.) water," Journal of Food and Nutrition Sciences, vol. 3, no. 8, pp. 1136-1143, 2012.

[63] C. K. Venil and P. Lakshmanaperumalsamy, "An insightful overview on microbial pigment, prodigiosin," Electronic Journal of Biology, vol. 5, no. 3, pp. 49-61, 2009.
[64] R. Siva, K. Subha, D. Bhakta, A. R. Ghosh, and S. Babu, "Characterization and enhanced production of Prodigiosin from the spoiled coconut," Applied Biochemistry and Biotechnology, vol. 166, no. 1, pp. 187-196, 2012. 